\title{
The Relevance Of Discourse Analysis For Translation Studies
}

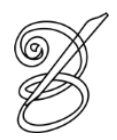

\author{
Alexandre Szeremeta \\ (Mestrando - UFSC) \\ alexandresz2011@live.com \\ Iliane Tecchio \\ (Doutoranda - UFSC) \\ iliane.tecchio@gmail.com \\ Roseni Silva \\ (Mestranda - UFSC) \\ rosenisilva@yahoo.com.br
}

\begin{abstract}
The present study aims at promoting a reflection on the relevance of the Discourse Analysis for the Translation Studies based on the theories of the main researchers for both areas. To do so, this paper is divided into three sections. In the first section, we deal with Discourse Analysis theories based on Brown and Yule (1983); Fairclough (1992) and Hatim and Mason (1990). In the second section, we present some aspects of the theories related to Translation Studies. In the following section, we raise some reflections regarding the interface Discourse Analysis and Translation Studies according to the theories presented previously. Finally, we present the conclusions concerning the research carried out in this paper.
\end{abstract}

Key-words: Discourse Analyses; Translation Studies; Discourse Analyses and Translation Studies.

Resumo: O presente estudo tem por objetivo promover uma reflexão acerca da relevância da Análise do Discurso para os Estudos da Tradução amparada em teorias de importantes pesquisadores de ambas as áreas. Para isso, este artigo está dividido em três seções. Na primeira seção, nós apresentamos algumas teorias sobre Análise do Discurso com base em Brown e Yule (1983); Fairclough (1992) e Hatim e Mason (1990). Na segunda seção, nós expomos algumas abordagens referentes aos Estudos da Tradução. Na seção seguinte, conduzimos uma reflexão relacionada à interface Análise do Discurso e Estudos da Tradução com base nas teorias elencadas neste estudo. Por fim, apresentamos as considerações finais do mesmo.

Palavras-chave: Análise do Discurso; Estudos da Tradução; Análise do Discurso e Estudos da Tradução.

\section{DISCOURSE ANALYSIS}

7 any different authors have tried to define what discourse is. Among these $\mathrm{M}$ researchers, Jaworski and Coupland (1999) mention Stubbs who states that "discourse is: language above the sentence or above the clause" (STUBBS, 1983, apud JAWORSKI; COUPLAND, 1999, p. 1); Fasold who says that "The study of discourse is the study of any aspect of language use" (FASOLD, 1990 apud JAWORSKI and COUPLAND, 1999, p. 1) and Candlin who declares that "Discourse refers to language in use, as a process which is socially situated" (CANDLIN, 1997 apud JAWORSK and COUPLAND, 1999, p. 3). However, the task of defining Discourse Analysis has revealed itself as a very difficult one because Discourse Analysis can be characterized as a way of 
approaching and thinking about anything (of a language) in any context, as McCarthy (1991) pointed:

\begin{abstract}
Discourse analysis is not only concerned with the description and analysis of spoken interaction. In addition to all our verbal encounters we daily consume hundreds of written and printed words: newspaper articles, letters, stories, recipes, instructions, notices, comics, billboards, leaflets pushed through the door, and so on. We usually expect them to be coherent, meaningful communications in which the words and/or sentences are linked to one another in a fashion that corresponds to conventional formulae, just as we do with speech (McCARTHY, 1991, p. 12).
\end{abstract}

Thus, according to McCarthy and Carter (1994, p. 38), a discourse-based view of language involves us in looking not just at isolated bits of language, but it involves examining how these bits contribute to the texts as a whole. Furthermore, it involves exploring the relation between the linguistic patterns of complete texts and the social contexts in which they function. This concept of considering the whole text as well as its function and purpose according to the social context in which it is inserted also applies to Translation Studies, as it will be discussed in the topics to follow.

Brown and Yule (1983, p. 1) add that "the analysis of discourse is necessarily the 144 analysis of language in use. As such, it cannot be restricted to the description of linguistic forms independent of the purposes or functions which these forms are designed to serve in human affairs." In this sense, related to this idea that Discourse Analysis deals with the study of any aspect of the language in use, Deborah Schiffrin (1994) emphasizes that:

\begin{abstract}
A definition of discourse as language use is consistent with functionalism in general: discourse is viewed as a system (a socially and culturally organized way of speaking) through which particular functions are realized. Although formal regularities may very well be examined, a functionalist definition of discourse leads analysts away from the structural basis of such regularities to focus, instead, on the way patterns of talk are put to use for certain purposes in particular contexts and/or how they result from the application of communicative strategies. (SCHIFFRIN, 1994, p. 32).
\end{abstract}

By this statement it's possible to say that Schiffrin goes beyond the concept of just studying the language in use. The researcher enlarges the view of Discourse Analysis with the idea of language being used for specific purposes, according to the contexts it is being used in. To illustrate this, the language we use among friends is not the same we use, for example, in the academic context. There are specific purposes and different hierarchical levels to be respected and the language is a way of demonstrating it. This is what Fairclough considers as discourse as well: "Discourse is for me more than just language use: it is language use, whether speech or writing, seen as a type of social practice" (FAIRCLOUGH, 1992, p. 28). 
For Fairclough, there is a dialectic relation between discourse and social structure. In his theory, he proposes to develop methods of discourse analysis that will allow studies of power in social relations, and analysis of social change as well. This theory is extremely important because it acknowledges the fact that there is a relation of power when it comes to social relations, and that this power is usually reinforced by discourse. As an example, we could cite the way a police officer interrogates a suspect of a crime or even a witness. His speech is constructed in order to reinforce his representativeness in the society he is part of.

It is necessary to highlight that this dialect relation between discourse and social structure mentioned by Fairclough can be negative when discourse is used to reinforce or justify some sort of behavior, concepts, prejudice, or even some sort of oppression within societies. As an example of oppression we can mention, in the past, the political discourses of Hitler, responsible for conducting a real massacre against the Jewish people. Nowadays, we have the political discourses in the Midwest, for instance, that has kept the population under a very strict control. So, through Fairclough's theory and the studies he proposes, there is the possibility of understanding, in a more plausible way, this power relation between discourse and society and, consequently, become aware that discourse can be used as a positive - or negative - tool in society.

Along these lines, it's possible to say then, that Discourse Analysis has risen as a fundamental tool to help scholars to discover, explore and understand the real "motivations" behind a text, a discourse or a translated text, for instance. As Brown and Yule (1983, p. 5) mention, discourse is a process in which communication evolves as an interaction between the participants. In this way, we could classify it as dynamic. The text, on the other hand, consists of the verbal record of discourse; the product of a communicative act, thus it can be considered static. Like so, the tools provided by Discourse Analysis enable the readers to read and interpret a text, for example, in a more critical way, raising awareness of any kind of motivation, intention or problem behind it. Discourse Analysis, according to Brown \& Yule (1983), is not supposed to give ready answers, but to lead the reader to find them out through critical thought.

Thusly, when it comes to Translation Studies, Discourse Analysis would not be responsible for discussing the validity of a theory, method or choice made by the translator. Actually, Discourse Analysis would focus on the existence and message of the texts and locate them within a historical and social context. According to Hatim and Mason (1990, p. 1) "In studying this complex process at work, we are in effect seeking insights which take us 
beyond translation itself towards the whole relationship between language activity and the social context in which it takes place". In other words, Discourse Analysis would aim at revealing the motivation involved in the arguing for or against a specific theory or method used in the Translation Study area.

\section{TRANSLATION STUDIES}

The term Translation Studies was first stated by Holmes in 1975 in the text The name and nature of translation studies, as an alternative to translation theory. His choice was justified by the fact that most part of the research carried out in translation doesn't match to the general understanding of "science", "theory". Thus, the term Translation Studies, according to Holmes, provides a wider epistemological flexibility to this field, acting as a definition for the whole discipline that includes many different categories and sub-categories.

It's hard to define, though, what Translation Studies is due to its interdisciplinary character, but we can define Translation Studies, based on Toro (2007) as

an academic discipline that studies the theory and practice of translation. It is, by nature, a multilingual but also interdisciplinary field of study since establishes relationships with linguistics, cultural studies, philosophy, the information sciences, and so forth (TORO, 2007, p. 9).

However, for some researchers, it is unclear whether Translation Studies is yet recognized as an independent academic discipline or not because it has been categorized as a sub-discipline under linguistics. Increasing the quality, breadth and depth of research into the multi-dimensional mental activity that is translation, it may help translation studies become an accepted academic discipline. Hatim and Mason (1990, p. 9) have pointed out that the status of translation studies has been improved by the establishment of departments of translation and interpretation studies training interpreters and translators, increased research interest from academics in other fields, and an increase in published research, academic exchanges and discussion worldwide. These factors promote Translation Studies, in their opinion, as an independent academic field, and they are all directly related to the development of translation research.

In this sense, considering Translation Studies as an independent and interdisciplinary discipline that deals with the study of translation, it's also important to point out that there are many different possible fields of study and a wide variety of approaches that can be applied to it. Munday (2009, p. 1) states that the information appears to be scattered throughout an endless number of books and journals and, sometimes, in texts from different disciplines, 
making the path of research much more difficult and confusing for the students and researchers.

In order to help students and researchers to overcome these drawbacks a series of collections, or readers, have been published to offer them some guidance as regards the key texts. Toro (2007) cites as the most noteworthy examples of such publications Chesterman (1989): Readings in Translation Theory; Lefevere (1992a): Translation/history/Culture: A Sourcebook; Schulte and Biguenet (1992): Theories of Translation: An Anthology of Essays from Dryden to Derrida; Venuti (2000): The Translation Studies Reader; Baker (1998): The Routledge Encyclopedia of Translation Studies; Hatim and Munday (2004): Translation: An Advanced Resource Book, and many other examples of important readings for the ones who might be interested in this area of study.

To enrich the list of important authors on Translation Studies mentioned by Toro (2007), we would like to add a very important - if not the most important - piece of work for this field The Map: A Beginner's Guide to Doing Research by Williams and Chesterman (2002). It is an example of current research methods and trends in Translation Studies. The former book focuses on the interdisciplinary characteristics as the essence of translation studies in view a view of its theoretical diversity, and signalizes the existence of a general theory of translation. The latter focuses on a description of research and research methods in translation studies. It systematically describes translation research and gives in depth but easy to understand explanations of translation research methods and processes. It's a very useful guide on Translation Studies, especially for the ones who are starting developing research in this wide area.

From the second half of the $20^{\text {th }}$ century up to the present days, many approaches on this research area have emerged, according to Toro (2007), the most significant are the theories of equivalence and comparisons between languages; the functionalist theories; the discursive approaches; the polysystem theory; cultural studies (in which we must point out the important role of the Brazilian cannibalistic movement - Arrojo (1995): The Death of the Author and the limits of the translator's Visibility; Vieira (1999): Liberating calibans: Readings of Antropofagia and Haroldo de Campos (1999): Poetics of transcreation); the philosophical and hermeneutic approaches; the integrating and interdisciplinary approaches.

Besides it, the most recent contributions to research into Translation Studies is related to corpus studies - highlighting the works on corpus published by Mona Baker in 1993, 1995 and 1996 - and the cognitive approaches that "focus their attention on the mental process that 
goes on inside the translator's head, that is, they are interested in translation as a cognitive activity" (TORO, 2007, p. 26)

Thus, with this brief overview on Translation Studies, we intended not only to present a definition for this wide research area, but also point out the progress and expansion it has gone through along the past decades. This progress is very significant and vital for the improvement of future researches in this field, in Toro's words "All in all, it could be said that we are now at a time when Translation Studies are blossoming and the range of perspectives open to the young researcher is enormous" (TORO, 2007, p. 31).

\section{THE INTERFACE DISCOURSE ANALYSIS AND TRANSLATION STUDIES}

Concerning to translation, with reference to concepts and methods derived from linguistics, pragmatics and Discourse Analysis have a strong tradition in Translation Studies. Schaffner $(2002$, p. 2) explains that one of the main reasons for that is because there is a "general agreement that understanding a text is a prerequisite for translating it". Understanding includes reflecting about the linguistics structures which a text displays and, as a result, the structure chosen by the author reflects the aims and purposes he wants to achieve with the text, in a specific sociocultural context and in a specific communicative situation. The current overviews recognize the fact that formal aspects of language have to be considered within the context of their use, with the effect that pragmatic; discourse and sociolinguistic dimensions also need to be considered. Hatim and Mason (1990, p. 101) remind us that "in order to perceive the full communicative thrust of an utterance, we need to appreciate not only the pragmatic action, but also a semiotic dimension which regulates the interaction of the various discoursal elements as 'signs'. [...] It is only through this interactive semiotic dimension that language users can begin to do things with words."

From this point of thinking about language, and relating it to translation concerns, Discourse Analysis can be seen as a tool to inspire translators and help them to make translation decisions as well as, a theory for developing translation competences. For example, the textual analysis that is studied in Discourse Analysis would in the long run guarantee the quality of the product, the translated text, as well as the process, the translation operation. This is due to the in-depth analysis of the source text is paramount to the quality of the target text. However, as Schaffner advices (2002, p. 5), when it comes to the translation activity it is not necessary a deep analysis of a text in its own right (for example, from comparative perspective in order to find what the conventions are of a particular genre and compare them with another culture), but identify textual features which are relevant for the 
process of translation. That is, an analysis needs to be understood as a translation oriented analysis. (For instance, identify and highlight specific textual features which might be expected to present translation problems in order to guide translation decisions).

In the widest sense, translation implies a "transfer" from one of at least two cultures, languages, modes and/or sign systems to another and that text/discourse production in the target culture, language, mode and/or sign system requires reformulation according to a set of parameters (for example, purpose, norms, recipient type). It is important to point out, then, that a text needs to be understood before it is translated, which requires world knowledge, individual understanding and inferences being secured by discourse analysis. Trosborg (2002, p. 9) asserts that understanding the text in full gives the translator a through overview and the possibility of maintaining or adapting the source text in a way to meet the demands of the target text skopos when producing the translated text.

Thus, Discourse Analysis and Translation are interrelated in terms of both involving: language in use and interaction such as, communicative acts sharing communicate parameters (for example, communicative settings and partners, their background knowledge profiles and perspectives); cognition manifested in text/discourse parameters (for example, meanings, inferences, coherence). Cristina Schaffner (2002, p. 1) emphasizes that the main object of linguistics is no longer the language system qua system, but aspects of how language is actually used in communicative situations. At the same way, Hatim and Mason (1990, p. xi) point out that "translation is regarded not as a sterile linguistic exercise but as an act of communication", and they also quote that it is important an integrated account of discourse processes to the practical concerns of the translator.

According to Nida (1996) the relevance of Discourse analysis to Translation Studies is that the more translators know about the structures and the dynamic of discourse, the more readily and accurately they can translate both the content and the spirit of a text. As translators are readers of a very special kind, the task is not only to understand the original but to make the translation understandable. To reach this task, the translators might guide the production of the translated text following, as an example, Paul Grice's Conversational Maxims (1975) studied in Discourse Analysis:

Maxims of Quantity:

1. Make your contribution to the conversation as informative as necessary.

2. Do not make your contribution to the conversation more informative than necessary.

The same applies to the translated text in which the translator has to be aware of the amount of information that needs to be provided so that the text reaches the reader successfully. 
Maxims of Quality:

1. Do not say what you believe to be false.

2. Do not say that for which you lack adequate evidence.

The translator is responsible for providing accurate information in respect of the text that will be translated.

Maxim of Relation:

1. Be relevant.

The translator is in charge of defining which information is relevant for the social, cultural and historical context of the translated text. Some allusions might be explained or even omitted to contribute to the readability of the translated text in a specific culture, for example.

Maxims of Manner:

1. Avoid obscurity of expression.

2. Avoid Ambiguity.

3. Be brief.

4. Be orderly.

These are steps that can help the translator to make decisions, mainly, when he/she deals with cultural aspects, such as idiomatic expressions, metaphors, sayings, humor, and so on.

Thus, faced with an original text, the translator will have to adopt some translation strategies. However, which of the roads to follow is a tactical decision taken by the translator. But, as we have discussed in this paper, in order to translate a source text analysis is necessary that takes into account both the intratextual and the extratextual factors of communication. These factors can be analysed with the help of Discourse Analysis.

\section{FINAL CONSIDERATIONS}

From what we have discussed in this paper, it is comprehensible that for the purpose of translating a text proficiently, the translator should be aware of the procedures of analyzing texts. The professional should begin analyzing the source text within the special cultural position of it. Then, formulate the translation strategies according to the relative position and differences between target culture and source culture; the translation aims and the special requirements of the target readers. As Nord $(2006$, p. 1) explains, translation - oriented text analysis should not only ensure full comprehension and correct interpretation of the text or explain its linguistics and textual structure, but it also should provide a reliable foundation for each every decision which the translator has to make in a particular translation process. Therefore, in the sense of translation, establishing clear text consciousness is rather significant not only in the practice of translation, but also in the research of translation.

On the other hand, we should be aware that it is not possible to solve all the problems faced in the task of translating a text through the Discourse Analysis theory, although this 
discipline does provide very valuable help for translators. For instance, text analysis can be applied to a source text to give translators insight into what translation problems it may present. When translators translate a text, they always deal with material within a certain text type or register (genre) and they have to develop skills to translate texts in specialized registers. Once more, Nord (2006, p. 9) highlights that it is the purpose that determines the requirements to be met by the translation. In conclusion, Translation Studies can make it useful to guide its practice with the help of other disciplines, but "they have to be integrated into an overall concept of translation that will serve as a permanent frame of reference for the translator" (NORD, 2006, p. 1). 


\section{REFERENCES}

BROWN, Gillian; YULE, George. Discourse Analysis. Cambridge: Cambridge University Press, 1983.

FAIRCLOUGH, Norman. Critical Language Awareness. London: Longman, 1992.

HATIM, Basil; MASON, Ian. Discourse and the Translator. London: Longman, 1990.

JAWORSKI, Adam; COUPLAND, Nikolas (Org.). The Discourse Reader. London and New York: Routledge, 1999.

HOLMES, James. The Name and nature of Translation Studies. In: VENUTTI, L. (Ed.). 2000.

MALMKJAER, Kirsten. Translation and Language Teaching. Manchester: St. Jerome Publishing, 1998.

McCARTHY, Michael. Discourse Analysis for Language Teachers. Cambridge: Cambridge University Press, 1991.

McCARTHY, Michael; CARTER, Ronald. Language as Discourse: Perspectives for Language Teaching. London: Longman, 1994.

MUNDAY, Jeremy. The Routledge Companion to Translation Studies. Revised Edition. New York: 2009.

152 NIDA, Eugene. The Principles of Discourse Structure and Content in Relation to Translating. In: KLAUDY, K.; KOHN, J. Proceedings of the $2^{\text {nd }}$ International Conference on Current Trends in Studies of Translating and Interpreting. Budapeste: Scholastica, p. 37-43, sept. 1996.

NORD, Christiane. Text Analysis in Translation. $2^{\text {nd }}$ ed. Beijing: FLT and Research Press, 2006.

SCHAFFNER, Cristina. The role of Discourse Analysis for Translation and Translator Training. Clevedon: Multilingual Matters, 2002.

SCHIFFRIN, Deborah. Approaches to Discourse. Oxford: Blackwell, 1994.

TORO, Cristina García. Translation Studies: an overview. Cadernos de Tradução. vol. 2, n.20, $2007 . \quad$ Disponível em: <http://www.periodicos.ufsc.br/index.php/traducao/article/view/1001>. Acessado em: 8 jun. 2012.

TROSBORG, Anna. Discourse Analysis as Part of Translator Training. In: SCHAFFNER, Cristina. The role of Discourse Analysis for Translation and Translator Training. Clevedon: Multilingual Matters, 2002. 